\title{
Ajaloo tunnistaja ehk Poola suulise ajaloo spetsiifikast
}

\author{
Marta Kurkowska-Budzan
}

Teesid: Artiklis tutvustatakse Poola suulise ajaloo põhilisi kujunemissuundi 1980. aastatest alates kuni tänapäevani. Käsitletakse suulise ajaloo ilmnemise institutsionaalseid, poliitilisi ja sotsiaalseid kontekste olukorras, kus suulise ajaloo projektide keskseks kontseptsiooniks on olnud ajaloo tunnistaja. Artiklis tõstatatakse küsimus selle kontseptsiooni epistemoloogilistest ja eetilistest probleemidest, mis pärinevad ajajärgust, mil suuline ajalugu hakkas Poolas kodanikuõpetuse historiograafia (avaliku ajaloo) raames välja kujunema.

Märksõnad: ajaloo tunnistaja, avalik (ametlik) ajalugu, mälupoliitika, Poola, suuline ajalugu

Samal ajal suulise ajaloo (oral history) populaarsuse tõusuga lääneriikides 1960. aastatel hakkasid ka teisel pool raudset eesriiet kõlama hääled, mis viitasid ajaloolaste võimalusele kasutada algallikaid (Kersten 1968). Mõjukaim ettepanek Poolas tuli professor Krystyna Kerstenilt, uusajaloo tunnustatud uurijalt, ning oli adresseeritud neile, kes soovisid oma uurimispagasit sotsioloogiliste meetoditega mitmekesistada. Kersten kirjutas: "[---] kogudes tunnistusi inimestelt, kes omal algatusel ei kõneleks ja kes ei jätaks jälgi oma aktiivsusest, ei saa [ajaloolane] kõrvale jätta spetsiaalseid sotsioloogilisi uurimistehnikaid ja -meetodeid, vastasel juhul on ta käsitööline, kes tegutseb kaasaegse vabriku kõrval" (Kersten 1971: 318). See oli üleskutse laiendada teadusliku tunnetuse piire, millel puudub seos selliste eetiliste postulaatidega nagu seda oli näiteks marksistlik ajalugu altpoolt kontseptsioon (history from below) (KurkowskaBudzan 2003).

Ent isegi siis, kui Poola (nagu ka teiste "vennalike" riikide) ajaloolased kasutasid suulisi andmeid (nt kogudes Teise maailmasõja veteranide meenutusi), ei huvitunud nad kuni 1989. aastani nendest ideedest, mis kujundasid suulise ajaloo arengut Läänes. Eeltsiteeritud Krystyna Kersteni 1960. aastatest pärit lauses leidub aga üks oluline märksõna, mida võib mõista kui tänapäeva Poola 
suulise ajaloo versiooni domineerivat sümbolit (seda vähemalt laia ühiskondliku toimimise tasandil). Selle sõna esinemine uusima ajaloo tunnustatud autori tekstis (mis esindab modernistide akadeemilisi püüdlusi epistemoloogiliselt tugevdada ajaloouuringuid) ei ole sümboolika seisukohalt sugugi tähenduseta. See sõna on "tunnistus", mis seostub Poola suulise ajaloo võtmeterminiga ajaloo tunnistaja.

\section{Ajaloo tunnistaja - probleemid tähenduse ja funktsiooniga}

Kui minna tagasi alguse juurde, siis suulisele ajaloole Kesk- ja Ida-Euroopa opositsioonilistes ringkondades pani aluse 1980. aastatel poliitiliselt marginaliseeritud või tagakiusatud isikute lugude kirjapanemine. Nende inimeste meenutused olid vastuolus ametliku ajalooversiooniga (Holzer 1990; Kałwa 2010). Pärast kommunismi kokkuvarisemist institutsionaliseerus see kodanikualgatus arhiveerimis-, haridus- ja uurimistegevuseks, identifitseerides seda tegevust suulise ajaloo kaudu. Valdkonna kirjeldatud kujunemislugu mõjutas Kesk-Euroopa suulise ajaloo spetsiifikat, mida iseloomustab Dobrochna Kałwa järgnevalt: "Lõpptulemusena oli suuline ajalugu nendes piirkondades oma algupäralt poliitiline ajalugu, sest hääle andmine kõrvaleheidetud rühmadele tähendas erinevalt demokraatlikest lääneriikidest hääle andmist poliitilise, intellektuaalse ja kultuurieliidi esindajatele, represseeritutele, marginaliseeritutele või valitsevast diskursist kõrvale jäetutele" (Kałwa 2010.)

Michael Frisch eristas 1990. aastal suulise ajaloo kaks suunda: "rohkem ajalugu" (more history) ja "anti-ajalugu” (anti-history) (Frisch 1990: 187). Rohkem ajalugu suunas on suulise teabe väärtuse mõõdupuuks teabe panus ühiskonna minevikutundmisse - saame "rohkem ajalugu", kogume teadmisi. Suulise ajaloo mõõde on siin eelkõige epistemoloogiline ning selle käsitlusviisiga on seotud nii informandi (või andmeesitaja) mõiste kui ka historiograafia klassikaline või kaasaegne mudel. Teise suulise ajaloo suuna puhul, nagu kirjutab Frisch, viiakse rõhk teabelt suulise pärimuse loomisprotsessile - alates esmakontakti loomisest kõnelejaga kuni uurimuse avaldamiseni. Sellist ajalugu kujundab eetiline imperatiiv. Esiplaanile nihkuvad kompenseerimisele viitavad alustõed, nagu hääle andmine neile, kel puudub võim, kes on privileegidest ilma jäetud, vaikijatele, marginaliseeritutele, kaotajatele.

Poolas tekkinud suulise kodanikuajaloo keskne mõiste on ajaloo tunnistaja, kelle mälu sai poliitilise võimuga opositsioonis olevate teadmiste allikaks. Frischi esitatud klassifikatsioon ei näi antud konteksti hästi sobituvat: vaatamata Poola suulise ajaloo alastes kirjutistes ilmnevate terminite kokkulangevusele 
lääne uurimustes kasutatavate oskussõnadega, hakkab siin silma soov ühendada eetiline postulaat epistemoloogilisega. Selle aluseks on Poola uurimistraditsiooni mitmesugustest põhjustest tulenev kiindumus ajaloouurimise etaloni vastu, mis koondub Aristotelese tõekategooria ümber.

Kuidas suulises ajaloos avaldub kirjeldatud epistemoloogilise ja eetilise alustõe ühitamine? Vastust tuleks otsida mõiste ajaloo tunnistaja tähendusväljast. Sõna "tunnistaja" kasutatakse poola keeles peamiselt juriidilises kontekstis. Muus tähenduses on see "millegi juures viibinud isik, kes võib kinnitada seda, mida ta nägi; juhtunu, sündmuse tunnistaja" (Markowski 1999: 1024). Ajaloo tunnistaja ühendab minu hinnangul mõlemad esitatud tähendused: ajalooliste faktide tuvastamise toimingule omistatakse ühiskondlikult ja kultuuriliselt selline kaal, mis on võrreldav juurdlusega kohtuprotsessis. Võrreldes juurdluses osaleva tunnistajaga tundub aga ajaloo tunnistaja usaldatavus olevat palju suurem. Ajaloo tunnistajal ja tema tunnistusel on informandi ja tema ütlusega võrreldes kõrgem epistemoloogiline staatus (nimetagem seda tõepärasuse näitajaks). Sõna "tunnistus" kõlab palju tõsisemalt ja on midagi palju keerulisemat kui "informatsioon”. Tunnistus anti Poola suulise ajaloo algusaegadel totalitaarset režiimi valvava ja selle režiimi poolt kehtestatud ametliku, võltsitud ajalookäsitluse vastu.

Teoreetiliselt on tunnistus võrdväärne teiste allikatega, mida hinnatakse allikakriitiliselt - see on klassikalise ajaloo reegel. Kui lähtuda aga poola kultuurikontekstist, tundub selline kriitika moraalselt küündimatu. Ajaloo tunnistajaks saadakse suulises ajaloos omamoodi nominatsiooni teel, mis asendab vaevatasu unustamise, vaikimise, senise või ametliku ajalookäsitluse (need ei pruugi tingimata olla samad) tagakiusamise eest. "Ajaloo tunnistajad on meie aja kangelased" (www.swiadkowiehistorii.pl), nad on austusväärsed inimesed, keda seatakse moraalselt kõrgemale, sest nad olid sõdade, režiimide ohvrid. Nad on sageli eakad, kuuludes lahkuvasse, seega ka hinnalisse põlvkonda. Järgmiste tunnistajate valimine, et nad räägiksid järgnevatele põlvkondadele minevikust, rajaneb arusaamale ajaloo pedagoogilisest rollist. Suulise ajaloo arvukate projektide plaanis - hoolimata sellest, kas tegemist on teaduslike ja dokumentaalsete või populariseerivate projektidega - on ajaloo tunnistaja kogu ettevõtmise telg.

Kui vaadata dokumentaalset tegevust, millega Poolas on tegelenud suured keskused, nt Karta (ja paljud teised), võib märgata, et nende temaatika, kronoloogia ja geograafiline ulatus hõlmab kõiki põhilisi poliitilisi ja ühiskondlikke sündmusi, mis on toimunud Poolas, poolakatega või mis on neid kõige enam puudutanud. Tekivad ja laienevad suulise ajaloo arhiivid, üha kiiremas tempos kasvab eri kohtades hoitavate audio- ja videosalvestiste arv, populaarsust koguvad koolides ja kultuurikeskustes korraldatavad hariduskonkursid ja -projektid. 
Nende üldteemad ja meetrites mõõdetavad intervjuud näitavad, mis projektide autoritele huvi pakub ning millele intervjuu tegemisel tähelepanu peab pöörama. Eelistatud teemadeks on näiteks sellised "ajaloo õppetunnid" nagu Teine maailmasõda, Siberisse küüditamine, juutide hävitamine, opositsioon Poola Rahvavabariigis, igapäevaelu Poola uusajaloo eri perioodidel jms. Niisuguse projekti kangelaseks olev ajaloo tunnistaja ei vastuta oma ütluste eest siiski täielikult. Seda, mida ta nägi või mille ta üle elas ning mille kohta ta tunnistusi annab, on juba keegi teine otsustanud. "Milles seisnesid teie ülesanded ülestõusu ajal?", “Kas mäletate oma esimest sõjajärgset päeva?” - sedalaadi küsimusi esitav ajaloolane soovib eelkõige kuulda tunnistaja versiooni sündmuse või sündmuse osade kohta, mille on ajaloolased varem ära määratlenud ning mida nimetatakse ajaloofaktideks. Näiteks ajaloo tunnistaja puhul, kes on veendunud, et on läbi elanud kolm maailmasõda, korrigeeritakse tema öeldu intervjuulehel vastavaks üldtunnustatud ajalooteadmistele. Teisalt, nagu juba mainisin, on samas suulise ajaloo suunas olemas ka usk tunnistajate abil uute faktide tuvastamise võimalikkusse. See on usk teabe edastamise viisi (minevikust tänapäeva), arvestades keelevälise kogemuse ja verbaalse skeemi seotust (sündmus / kogemus - mällu salvestamine - taasesitamine - keeleline edasiandmine). Viimatimainitust hoolimata liigitaksin tunnistaja rolli ajalooliste teadmiste seisukohalt epistemoloogilises kontekstis teisejärguliseks. Eetilises plaanis on ta aga kahtlemata keskne kuju.

\section{Ajaloo tunnistaja populaarteaduslikus võtmes}

Suulist ajalugu mitte ainult ei tutvustata Poolas juba aastaid, seda propageerivad laial ühiskondlikul diapasoonil riigi- või pealinna asutused ja institutsioonid: Rahvusliku Mälu Instituut (Saksa Gaucki Instituudi analoog), rahvuslik kultuurikeskus (kultuuri- ja rahvuspärandi ministeeriumi koosseisu kuuluv keskne institutsioon) ja 1944. aasta Varssavi ülestõusu muuseum (mida rahastatakse Varssavi linna eelarvest). Need institutsioonid mängivad olulist ühiskondlikku rolli tänapäeva rahvusliku mälu "mängus" - nende käsutuses on vahendid, peamiselt rahalised, mis annavad võimu teatud minevikuteadmiste ja -tõlgenduste loomisele.

Ajaloo tunnistaja positsioon piiritletakse minevikuainelisi arutelusid kujundavates populariseerivates ettevõtmistes täpsemalt, kui teaduslikes uuringutes. Sellest tulenevalt tutvustan järgnevas mõnda sellist algatust, mille on ellu kutsunud aktiivsemad ja mõjukamad Poola suulise ajaloo keskused: Ajalooga Kohtumise Maja suulise ajaloo arhiiv, keskuse Karta algatusel loodud suulise ajaloo arhiiv, 1944. aasta Varssavi ülestõusu muuseum, Rahvusliku Mälu 
Instituudi saade "Ülestähendused" ja neile tasakaaluks - väljaspool pealinna tegutsev ja kohalikest vahenditest rahastatav Lublini keskus Brama Grodzka (tõlkes: linnavärav) - Teatr NN. Samuti tuleb ära märkida ettevõtmine, mis enam ei jätku, kuid mille veebileht on seni alles ning mis on interneti otsingumehhanismide tõttu väga tõhus "märgi ülesehitamises" ehk teisisõnu mõiste semantilise tausta kujundamises - see on "swiadkowiehistorii.pl" (tõlkes: ajaloo tunnistajad). Nimetatud veebilehe rajanud institutsioon, ehk rahvuslik kultuurikeskus, on tähtis kultuuripoliitika eesmärke realiseeriv riiklik keskus.

\section{4.pl ja audiohistoria.pl - Varssavi kogemus}

2004. aastal toonase Varssavi linnapea Lech Kaczyński (hilisema Poola Vabariigi presidendi) avatud Varssavi ülestõusu muuseum on Poola kaasaegse ajaloopoliitika lipulaev (Kostro \& Merta 2005). Kommunistlik režiim häbimärgistas Varssavi ülestõusu, sellest osavõtjaid aga kiusati taga, ja hiljem vaikiti sellest sootuks. Muuseumi eesmärk oli murda vaikimine ning anda 60 aastat hiljem au ülestõusnutele ja Poola iseseisvuspüüdluste ideele, mille traditsioon ulatub 19. sajandisse, samuti Poola respublikanismile. Varssavi ülestõusu muuseumi suulise ajaloo arhiivis asub ligikaudu 2700 ülestõusust osavõtja ütluste audioja videosalvestist, mida kasutatakse püsiekspositsioonis ja ajutistel näitustel, mis on kättesaadavad muuseumi lugemistoas ja veebilehel.

Muuseumi töötajad ja vabatahtlikud on endale ülesandeks võtnud Varssavi ülestõusu mällu kinnistamise, enne kui lahkub sellest osa võtnud põlvkond: "Meie soov on, et sel viisil kogutud tunnistused oleksid meie au- ja tänuavaldus veel meie seas viibivatele ülestõusust osavõtjate põlvkonnale, samuti nende lahkunud seltsimeestele" (www.1944.pl). See ülesanne on ühendatud sooviga dokumenteerida ja edastada objektiivseid fakte: "Suulise ajaloo arhiivi idee on ülestõusu tunnistajate räägitu kõige usaldusväärsem edasiandmine, seetõttu ei kaasa me salvestistesse peaaegu üldse muuseumi veebilehel kättesaadavaid mälestusi: me ei esita objektiivset ajaloolist narratiivi, vaid 1944. aasta sündmustes osalejate subjektiivseid ütlusi. Just sellises vormis on need salvestatud ja ainult nii saab neist terviklik arhiivimaterjal. Niisuguse ebaobjektiivse narratiivi näiteks on väga sageli ülestõusnute meenutustes mainitavad ukrainlastele omistatavad massimõrvad ja tsiviilelanike röövimine Varssavi ülestõusu ajal. Üleüldine kalduvus nimetada ukrainlasteks kõiki vene keelt kõnelevaid, kuid sakslaste poolel võidelnud rahvaid tekitab suurt poleemikat ja mittemõistmist. Õnneks on mitmed teaduslikud ajaloopublikatsioonid seda küsimust juba selgitanud.” (www.1944.pl.) 
Kõik salvestatud intervjuud on kirjalikult täisversioonis saadaval internetis. Nende sõnastust ja keelt on toimetatud. Arhiivikogusid saab kasutada ajaloouuringuteks ja koolituseesmärkidel ning neid käsitatakse ajalooliste allikatena koos kõige selle juurde kuuluvaga. Jutustaja on ajaloo tunnistaja, kes annab ütlusi ajalooliste sündmuste kohta ehk teisisõnu esitab poliitajaloolisi fakte. Uurimise seisukohalt on kõige olulisem tekstides esitatav faktiteave, mis nõuab ajaloolaselt nende ütluste tõepärasuse kriitilist hindamist. Seega esindavad need lood minevikuesitusi, andes möödaniku kohta teadmisi klassikalise ajalooteaduse reegleid järgivalt. Ütluste fragmente kasutatakse Varssavi ülestõusu muuseumi püsiekspositsiooni osas nimega "Tunnistaja telefon". Ekspositsiooni selles osas välja pandud sõjaeelsete telefonipiltide kõrval seisavad aparaadid, mille toru tõstes saab kuulda valitud ülestõusnute salvestatud jutustusi. Ülestõusnute portreed ripuvad seinal telefoniaparaatide kohal. Kaasaegsete vahenditega pikitud muuseumiekspositsioonis kasutatakse suulise ajaloo arhiivi salvestisi veel mitmes kohas, kuid kirjeldatu on minu arvates neist kõige märkimisväärsem. Sellest kohast alustavad külastajad oma muuseumiringkäiku: Varssavi ülestõusu ajalugu saab alguse selle osavõtjate mälestustest. Minu arvates annab ka näituse selle osa plastilise korralduse tõsielulisus edasi suulise ajaloo ideed sellisena, nagu näikse seda mõistvat muuseumi loojad juurdepääsuvõimalusena teabele minevikust.

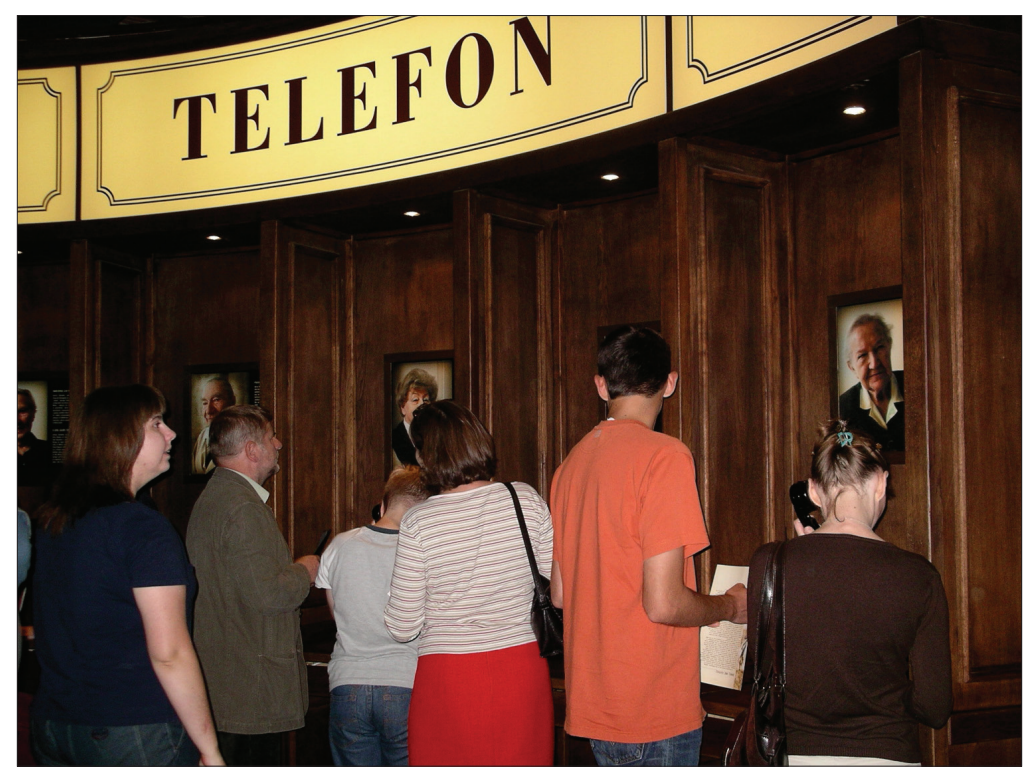

“Tunnistaja telefon”. Marta Kurkowska-Budzani foto. 
Parimaks Poola muuseumiks peetav kaasaegseim ja populaarseim Varssavi ülestõusu muuseum on oma olemuselt avalikus, eeskätt füüsilises ruumis toimiv institutsioon. Selle tegevus väljub aga hoone seinte piiridest - projekt "Virtuaalne muuseum" on vaatemänguline, internetis kättesaadav ettevõtmine, mis esitleb flash 3D animatsiooni kaudu tõetruult Varssavi ülestõusu muuseumi sisemust ja eksponaate. Võib väita, et virtuaalne ekspositsioon kaalub üles
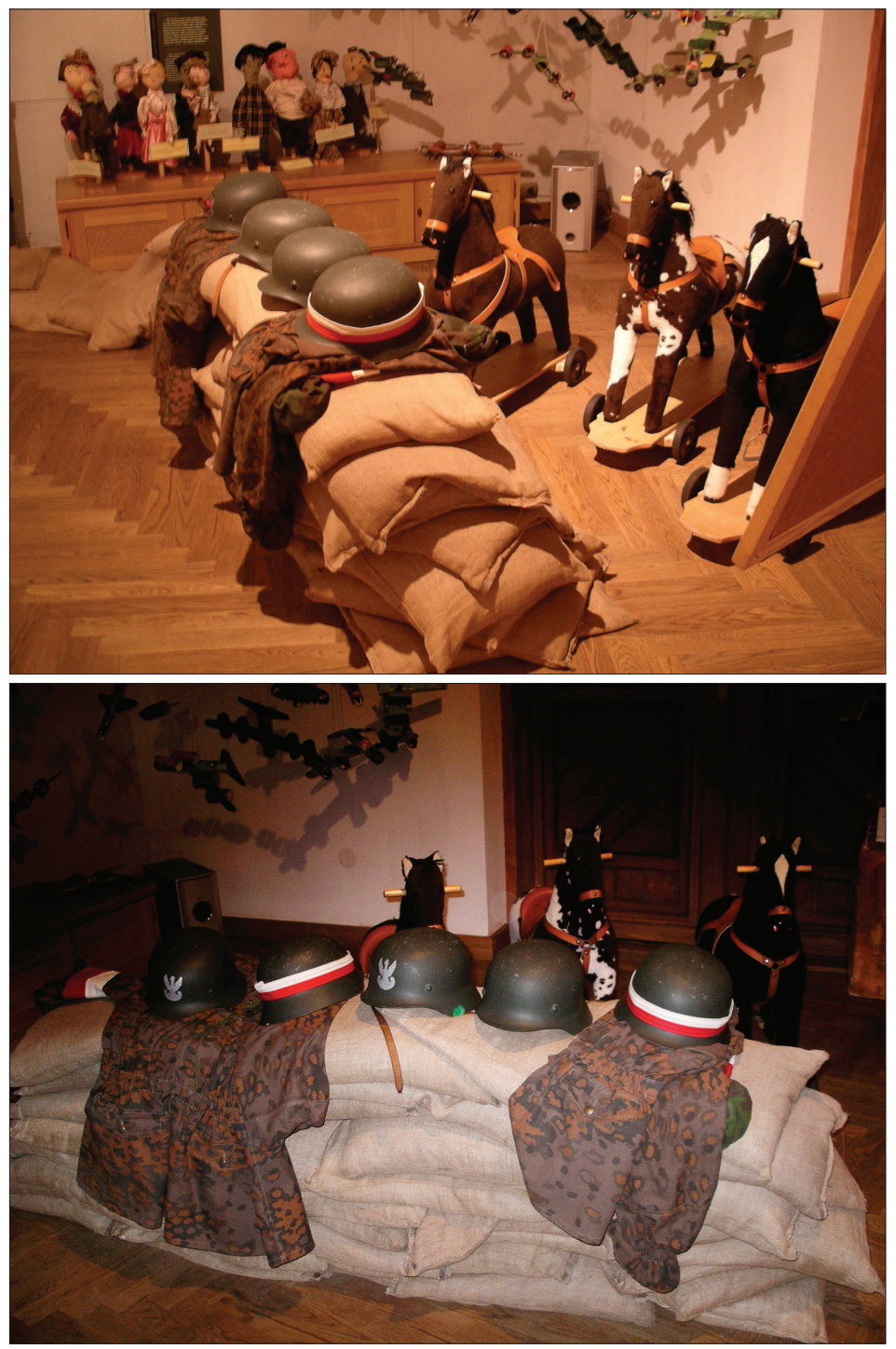

"Väikeste ülestõusnute tuba": laste mängunurk muuseumis. Marta Kurkowska-Budzani fotod. 
tegeliku - külastajat juhib giidi hääl, külastaja ringkäik ei ole ajaliselt piiratud, tänu eksponaatide nimistule ja võimalusele neid lähedalt vaadata ei jää kahe silma vahele ka kõige pisemad detailid, kõiki multimeediamaterjale (filmid, helisalvestised, fotod) on võimalik soovi korral taasesitada ning selleks ei pea seisma järjekorras. Samuti saab "helistada" ülestõusnule ja kuulata tema lugu. Peale ekspositsiooni koopia paiknevad virtuaalses muuseumis ka andmed suulise ajaloo arhiivi kogudest koos nendest intervjuudest tehtud videosalvestiste mõneminutiliste fragmentidega.

Reklaamikampaania, mida Varssavi ülestõusu muuseum meediavahendite kaudu oskuslikult korraldab, ja mida tänapäeval ei saa enam nimetada traditsiooniliseks, ehk siis televisioonis, raadios ja kirjutavas ajakirjanduses edastatavaks, annab tunnistust selle asutuse hiiglasuurest mõjust avalikule arvamusele. Igal aastal kaasnevad ülestõusu puhkemise aastapäeva tähistamisega esinemised elektroonilises meedias, dokumentaalfilmide linastused, planeeritud üritused Varssavis: kontserdid, avalik-õiguslikus televisioonis üle kantavad lahingute rekonstruktsioonid. Reklaamitakse "Virtuaalse muuseumi" veebilehte, rõhutatakse tõika, et Varssavi ülestõusu muuseumi ekspositsioon on oma multimeediumlikkuse tõttu kaasaegseim Poolas ja üks parimaid KeskEuroopas. Räägitakse palju "sündmuste tunnistajatest” ja suulise ajaloo meetodist. Minu hinnangul on suuline ajalugu eksisteerinud avalikkuse hulgas kui võrdväärne ajalootunnetuse haru just tänu Varssavi ülestõusu muuseumile.

Samuti on selgelt rõhutatud Varssavi ülestõusu muuseumi poliitilist profiili - see esindab konservatiivset, "respublikaanset" voolu. Muuseumi direktor Jan Ołdakowski oli 2011. aastani Poola Vabariigi Seimi saadik erakonna "Õigus ja õiglus" ridades. Selle kokkusattumuse tõttu assotsieerub suuline ajalugu tugevasti just restoration of memory'ga - tegevusega "Poola ajaloo õige pale" taastamiseks, ning "Poola ajaloopoliitika" programmiga, mille on visandanud Konservatiivse Mõtte Keskuse intellektuaalid (Kostro \& Merta 2005).

Samamoodi näib suulise ajaloo ülesandeid visandavat keskus Karta, millel on suurim suulise ajaloo arhiiv Poolas (umbes 4000 audiosalvestist ja 100 videosalvestist), millele pani aluse Idaarhiiviks kutsutav kollektsioon. Keskuse Karta elluviidavate projektide temaatika käsitleb totalitaarsete režiimide kogemusi, Hitleri ja Nõukogude okupatsiooni Poolas, koonduslaagreid, III Reichi sunnitöölisi, poolakaid Idas, vastupanu kommunismile ning elu sõjaeelses Poolas (mõisnikud, idas kaotatud ääremaa Kresy Wschodnie). Samuti räägitakse küsimustest, mida "Poola ajaloopoliitika" autorid on poolakate rahvusliku identiteedi kujundamise seisukohalt fundamentaalseteks nimetanud (Kostro \& Merta 2005).

Internetiportaal Audioajalugu, mille eestvedajaks on Ajalooga Kohtumise Maja koostöös keskusega Karta (Ajalooga Kohtumise Maja on keskuse Karta 
töötajate ja vabatahtlike poolt ellukutsutud institutsioon, millel on pealinna eelarvest rahastatava linna kultuuriasutuse staatus), esitleb suuliste ütluste arhiivi valikuna temaatilistesse esitlustesse koondunud fragmentidest, mis sisaldavad ajaloo tunnistajate tänapäevaseid ja arhiivifotosid, biograafilisi andmeid ning heli- ja tekstikatkeid ütlustest, mis manavad silme ette pilte nende inimeste elust. Esitlused - omamoodi virtuaalnäitused - on loodud suulise ajaloo põhiprojektide toel, mille eestvedajaks on Ajalooga Kohtumise Maja koostöös keskusega Karta: "Poolakad Idas", "Mauthausenist pääsenud”, "Sunnitööliste saatused”, "Unustatud natsilaagrid", "Poola-Saksa mälu. Krzyż Wielkopolski valla toonaste ja praeguste elanike elulood" (www.audiohistoria.pl).

\section{Rahvusliku Mälu Instituudi "Ülestähendused"}

Eespool nimetatud institutsioonide hulgas on suurim Rahvusliku Mälu Instituut. On paradoksaalne, et vaatamata selle instituudi käsutuses olevale suhteliselt ohtrale rahale ja tugevale organisatsioonilisele baasile ei ole juba mitu aastat tegutsenud Rahvusliku Mälu Instituudi avaliku hariduse büroo projekt, mille teemaks on "Ülestähendused - ajaloo tunnistajate ütlused". Seega ei ole instituut sama tuntud ja suulise ajaloo uurimisega seostatav kui teised eelpool tutvustatud institutsioonid ja projektid. Avaliku hariduse büroo korraldab noortele konkursse, mille ülesandeks on suuliste ütluste dokumenteerimine valitud teemadel (nt "Räägin sulle vabast Poolast"). Paraku piirdub see tegevus vaid kooliringkonnaga. Saade "Ajaloolised ülestähendused" oli avalik-õigusliku televisiooni eetris, nii telekanalis TVP1 kui ka teemakanalis TVP Historia, samuti on see pidevalt kättesaadav Poola televisiooni nõudevideotes. Seda reklaamitakse kui saatetsüklit, mis on pühendatud "erakordsetele isiksustele, inimestele, kelle ellu sekkus suur ajalugu ning kes sellele mehiselt vastu astusid" (http:// vod.tvp.pl/audycje/historia/notacje-historyczne).

Teadusringkonnas traditsioonilisteks uurijateks peetavad Rahvusliku Mälu Instituudi avaliku hariduse büroo ajaloolased deklareerivad: "Osalejate või kasvõi oluliste sündmuste vaatlejate tunnistuste (suuline ajalugu) dokumenteerimist peetakse õigusega samasuguseks uurimismeetodiks nagu kõiki teisigi" (http://ipn.gov.pl/bep/projekty-dokumentacyjne/program-notacje). See lause viitab tabavalt saate "Ülestähendused" loojate seisukohale küsimuses, mis on ütlus ja kes on ajaloo tunnistaja - huvi keskmes on "olulised sündmused", "suur ajalugu". Saate autorid jätkavad: "Meie saate "adressaatideks" olid eeskätt need inimesed, kes oskasid anda teavet Teise maailmasõja ja Poola Rahvavabariigi alguse kohta. [---] Aja jooksul hakkasime dokumenteerima ka kommunismivastase liikumise tegevust Poola Rahvavabariigis; [---]" (http:// 
ipn.gov.pl/bep/projekty-dokumentacyjne/program-notacje). Ajaloo tunnistaja on seega tüüpiline teabeallikas (sotsioloogilise nomenklatuuri järgi informant), intervjuu mõõde peab aga olema üksnes tunnetuslik. Biograafia ja selle koostamise küsimused, nagu ka mälu ja eetika küsimused ei kuulu selle saatega seotud ajaloolaste huviorbiiti (Kurkiewicz 2009).

On huvitav, kuidas mõjutab mõiste ajaloo tunnistaja määratlemist Rahvusliku Mälu Instituudi teist laadi tegevus, mis leiab laialdast kajastamist meedias. Pean silmas 2009. aastast välja antavat iga-aastast auhinda "Ajaloo tunnistaja", mille pälvivad Poola eri piirkondadest pärit "poola rahva ajaloo mäletamisel eriliste teenetega" inimesed ning Rahvusliku Mälu Instituudi haridussektori toetajad. Aastaauhind "Ajaloo tunnistaja" täiendab üleriigilist Rahvusliku Mälu Instituudi auhinda "Rahvusliku mälu hoidja”, mille eesmärk on "taastada austus rahva mineviku vastu, kaitsta väärtusi, tänu millele on Poola ikestamise aastatel vastu pidanud" (http://ipn.gov.pl/o-ipn/nagrodakustosz-pamieci-narodowej). Selles tõdemuses on tegemist ajaloo tunnistaja pisut teistsuguse määratlemisega - ühelt poolt käsitleb Rahvusliku Mälu Instituut teda "nagu kõiki teisi" ajalooallikaid, teisalt on ajaloo tunnistaja tihedalt mälu, rahvusliku identiteedi ja moraalsete väärtustega seotud figuur.

\section{Swiadkowiehistorii.pl - patriotism tarbimismaailmas}

Rahvusliku kultuurikeskuse projekt “Ajaloo tunnistajad” loodi 2006. aastal online-digitaalarhiivina ja suulise ajaloo saadete interneti-andmebaasina Poolas (www.swiadkowiehistorii.pl). Rahvuslik kultuurikeskus on riiklik kultuuriasutus, mille põhikirjajärgne tegevusala on "rahvusliku ja riikliku tava hoidmine ja levitamine" ning "Poola rahvuspärandi kui Euroopa kultuuripärandi osa edendamine" (www.nck.pl). Selle asutuse loomise algatas Kazimierz M. Ujazdowski, tollane kultuuri- ja rahvuspärandi minister, üks "Poola ajaloopoliitika" autoritest.

Saate "Ajaloo tunnistajad" veebileht ei ole võrreldav "Varssavi ülestõusu virtuaalmuuseumi” esitluse tehnoloogiaga, samuti ei ole arhiivikogu ülejäänud Poola suulise ajaloo arhiividega võrreldes kuigi suur. Siiski on see projekt tähendusrikas, sest suulise ajaloo esituskeskse ja konservatiivse käsitluse seisukohalt võtmerolli mängiva ajaloo tunnistaja mõiste kasutamine pealkirjas asetab selle projekti oma valdkonna liidri rolli. Seda vähemalt inimesele, kes internetis informatsiooni otsides sisestab otsingumootorisse väljendi "ajaloo tunnistaja”. Pärast rahvusliku kultuurikeskuse saate veebilehe aadressi saamist on käes võti Poola suulise ajaloo varamusse - rikkalikku andmebaasi ja projekti atraktiivsele arhiiviandmete esitlusele. 
"Ajaloo tunnistajate" projektis on kesksel kohal isik, kuid kontekst on alati traumaatiline, poolakate raske ajalugu - vabaduse kaotus ja võitlus selle tagasisaamise nimel. Selle tõendiks on teemade süstematiseerimine portaali otsingumootoris. Just teemad annavad üksikutele jutustustele ja saatustele raamid ja olemise mõtte. Kirik Poola Rahvavabariigis, poolakate mõrvamine Volõõnias, ametiühingute liit Solidaarsus, koonduslaager, KGB ohvrid, Saksa okupatsioon, Nõukogude okupatsioon, poolakad NSV Liidus, Poola põrandaalune riik, Poola relvajõud Läänes, Varssavi ülestõus, ümberasumised pärast 1945. aastat, juutide päästmine, mõisnikud.

Veebilehel avaldatavad lood on kirjanduslikud, neid on täiendatud, lisades subjektiivse jutustuse konteksti selgitavaid fakte, sh daatumeid. Intervjuu tegija on anonüümne, meile ei ole teada küsimused, mida ta intervjueeritavale esitab. Arhiiv ei võimalda tutvuda intervjuu originaalsalvestise ega transkriptsiooniga. Seega on veebileht swiadkowiehistorii.pl teatud määral toimetatud ajalooline ümberjutustus, mille missioon on sõnastatud ühemõtteliselt: "Tahame hoida mälestust inimestest, kes möödunud sajandi rasketel hetkedel on end näidanud tublide kodanikena või olnud seni vähe tuntud, kuid oluliste ajaloosündmuste tunnistajaks." Suulist ajalugu mõistetakse siin kui "unustatud kangelaste" hääle tugevdamist, mitte aga kui võimalike uuringute ajaloolist allikat, hoolimata sellest, et ütlusi käsitatakse "tunnistustena" ehk mineviku esindamisena. Selline inimeste "avastamine" ehk unustusest leidmine käib käsikäes rahvusliku kultuurikeskuse missiooniga, milleks on (rahvuspärandi ja -kultuuri jms) edendamine. Selline perspektiiv võimaldab rahvuslikul kultuurikeskusel ületada ajaloohariduse tavapäraste etalonide piire. Näiteks võib tuua ühiskondliku aktsiooni, saate "Ajaloo tunnistajad" lahutamatu osa, mis seisneb selles, et avalikes ruumides (mis ei seondu haridusvaldkonnaga ning kindlasti mitte ajalooga, näiteks suurlinnade tänapäevastes kaubanduskeskustes) seati üles multimeediakioskid helisalvestiste ja mõneminutiliste lühifilmidega, mis on loodud projekti arhiivi kogunenud materjalide põhjal. Filmide kangelasteks on alampolkovnik Janusz Brochwicz-Lewiński - Micheli lossi kaitsja Varssavi ülestõusu ajal; Wilhelm Brasse - Auschwitzi koonduslaagri fotograaf; Jarosław Hyk - opositsionäär Wrocławist (kogu maailmas tuntud fotol kujutatud inimene, kellest sõitis režiimivastase meeleavalduse ajal üle miilitsaauto); Tomasz Strzyżewski, kes viis 1970. aastatel salaja riigist välja tsensuuri käsiraamatu ja avaldas selle Läänes. "Sel uuel ja ka noore põlvkonna jaoks huvitaval moel tahame rääkida minevikust ja ärgitada mõtlema tulevikule," deklareerivad aktsiooni algatajad. Väärtused, mida rahvuslik kultuurikeskus kaubanduskeskuste klientidele multimeediaesitluste kaudu pakub, on patriotism, vaprus, ausus, solidaarsus. Rahvuslik kultuurikeskus on oma idee poolest (mis on ja mis võib olla avalik ruum ning kuidas selles toimima panna ajalugu) lähedane Lublini keskusele Brama Grodzka - Teatr NN. 


\section{Tnn.lublin.pl - kohalolek ja mälu}

Keskus Brama Grodzka (tõlkes: linnavärav) - Teatr NN Lublinist (Poola idaosas) on oma tegevuse algusaegadest saadik seostunud oma asukoha Brama Grodzka sümboolse ja ajaloolise tähendusega, mis vanasti tähistas läbikäiku kristlaste ja juutide linnaosa vahel, samuti Lublini asukohaga kultuuride, traditsioonide ja religioonide ristumispunktis. "Kui pidada "mälu" ja "kohta" põhikategooriateks inimese eksistentsis ajas ja ruumis, võib "kohalolekut" tõlgendada teatud ruumilis-ajaloolises tegelikkuses viibiva indiviidi samasuse põhilise mõõdupuuna. "Mälu - koht - kohalolek" - see on alates 1992. aastast Lublinis keskuse Brama Grodzka - Teatr NN elluviidav programm, mille aluseks on identiteedi ja kohalikke kogukondi ühendavate sidemete rekonstruktsioon kohamälu juurde pöördumise kaudu" (Kubiszyn 2003: 91).

Tavade tunnustamine ja ellukutsumine peab kaasa aitama identiteedi kujundamisele, mida mõistetakse kaasatud kohalolekuna. Siinkohal on sobiv meetod just suuline ajalugu, tänu millele on võimalik kohaliku kogukonna kaudu taasleida oma minevikku, arendada konventsionaalsete ajalooteadmiste skeemist vaba identiteeti, hoomata iga sellise kogukonna liikme individuaalsust ning avastada nende panust kogu rühma saavutustes. Keskuse Brama Grodzka - Teatr NN suulise ajaloo programmi käsutuses on enam kui 1600 inimese mälestuste salvestised. Peamised vestluste ajal käsitletavad teemad on igapäevaelu, kooliharidus, mitmekultuurilisus, Teine maailmasõda, hukkamine, poolakate ja juutide suhted Teise maailmasõja päevil, poliitiline opositsioon ja sõltumatu vastupanuliikumine Poola Rahvavabariigis, olulised sündmused Lublini ja selle elanike uusimas ajaloos, kultuurielu, lublinlaste rahvakultuur. Keskuse töötajad ei käsita suulisi ütlusi hariliku arhiivimaterjalina - fiktsioonide ja fiktsionalismi tunnustega suulisi pärimusi tuleb nende hinnangul tõlgendada tõekategooriate kaudu, mis erinevad standardist, nn objektiivsest või ajaloolisest tõest. Eeldatakse, et kogutud ütlused kujutavad inimeste kogetut selliselt, nagu nad seda ise näevad, subjektiivsel perspektiivil ja subjektiivsetel mõistetel on aga ülimus objektiivselt aset leidnud olukorra üle. "Inimesed jutustavad igapäevaelust ja selle hõngust: nad meenutavad oma naabreid, oma kodumaju ja -tänavaid, manavad silme ette mälupilte lapsepõlvest ja möödunud aastate õhkkonda. Nad meenutavad ka okupatsiooniperioodi ja uusima aja dramaatilisi sündmusi. Kogutud mälestused on linna nüüdisajaloo hindamatu dokument. Tulevikus hakkavad seda kasutama ajaloolased, sotsioloogid ja keeleuurijad. Meie tegevuse eesmärk ei ole aga üksnes kogutud mälestuste dokumenteerimine ja arhiveerimine. Registreeritud meenutusi kasutatakse ka haridusalastes ja loomingulistes ettevõtmistes" (Pietrasiewicz 2010). Nagu 
omamoodi kirjandus, pakuvad Lublini elanike meenutused keskusele Brama Grodzka inspiratsiooni ning lõuendit uueks loominguliseks jutustuseks. Siia kuulub näitus "Kohamälu", mis on välja pandud mitmekorruselise väravahoone käänulistes koridorides. Näitusel on väljas vanad fotod, jutustuste salvestised ja arhiividokumendid. Keskuse idee algataja ja direktor Tomasz Pietrasiewicz: "Sel moel on tekkinud omalaadne "Mäluteater". Igapäevaselt on keskuse ruumi täitev stsenograafia näiliselt elutu. Näituse osaks olevate tulede ja helide sisselülitamine elavdab ruumi niivõrd, et selle paiga müürid justkui hakkaksid olematu linna pildikeste ja "muusika" kaudu jutustama oma lugu. Võime kuulda vankrirataste kolinat tänavasillutisel, kirikukelli, turuplatsi saginat koos juudist kaupmehe hõigetega, mänguhoos laste kilkeid, juudi rahvalaulu. Brama Grodzka akna vastas, kust on näha juudi linnaosa tühermaad, ripub seinal peegel. See silm - väravahoones paiknev peegel - peegeldab seda tühermaad, "kisub" seda väravahoone sisemusse. See sümboolne detail tähendab, et just meie, värava peremehed, võtame endale vastutuse selle mäletamise eest, mis kunagi väravahoone akna taga oli.” (www.tnn.lublin.pl/k_26_m_26.html.)

Tuleb rõhutada, et näitusel kasutatud ajaloo tunnistajate ütlused ei ole infokandjad, vaid need loovad võrdselt muude helidega iseseisva helimaastiku. Nende kõige intrigeerivamad osad on trükitud hiiglasuurtele laest alla rippuvatele lõuendipalakatele, mille ülesanne on meelitada külastajat tutvuma ütluste täisversiooniga keskuse veebilehel või arhiivis. Keskuse Brama Grodzka - Teatr NN spetsiifika on loominguline tegevus linnaruumis ja selle tegevuse esiplaanil on alati eetilised väärtused. Tähelepanu väärib 2000. aastal algatatud projekt "Mälumüsteerium". Müsteerium "Kohamälu" (2002) oli loominguline katse võtta mõõtu mälestustega kohast, mida iseloomustasid hukkamised, julmus, häving. Projekti olid kaasatud tavalised linnakodanikud, läbisõitjad, noored. Osalejate õhtune rongkäik algas väljumisega tuledesäras ja elust pulbitsevast vanalinna osast ja sisenemisega läbi linnaväravate teisel pool valitsevasse pimedusse - sinna, kus kunagi oli olnud juudi linnaosa ja kus seisab loss, mis Teise maailmasõja ajal ja mõned aastad pärast selle lõppu oli kahe totalitaarse režiimi käes, mille esindajad hukkasid seal tuhandeid inimesi. Müsteeriumist osavõtjaid juhtis lahtistest kanalisatsioonikaevudest järgemööda süttiv valgus. Kaevudesse olid paigaldatud ka kõlarid, kust kõlasid lossis vangistuses hoitud inimeste jutustused ning Lublini elanike meenutused juudi linnaosast ja selle hävitamisest. Keskuse Brama Grodzka - Teatr NN müsteeriumid taastavad kunsti ja emotsioonide kaudu mälestused linnast ja selle identiteedist, need on humanitaarne läkitus kaasaegsetele.

Mälestustes olemasoleva Lublini taaselustamisel põhinevad keskuse programmid keerlevad märksõna kohalolek ümber. See kohalolek väljendub osaluses 

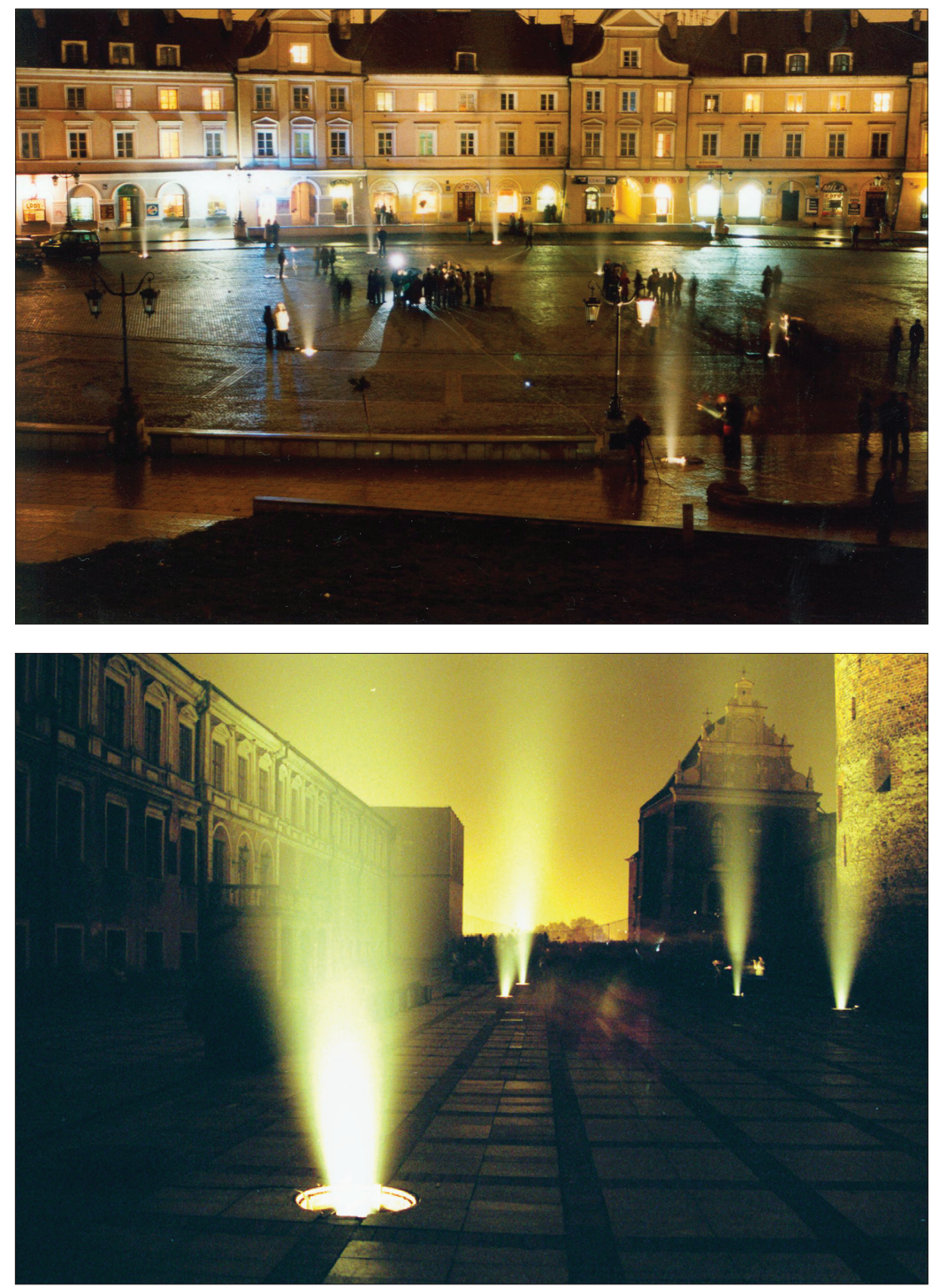

“Mälumüsteerium” Lublinis 2002. aastal. Marta Kubiszyni fotod.

ja sõnas, suulises tunnistuses. Nagu dialoogi puhul, on ka kohalolekus vajalik teine pool, seega on Teatr NN-i lavastatud sündmustes osaleja-vastuvõtja teine tunnistaja, kes kuulab teise inimese, keda sageli enam ei ole, tunnistusi. 


\section{Tunnistaja või jutustaja?}

Suuline ajalugu on algusest peale kogunud populaarsust harrastusajaloolaste, noorsoo, õpetajate ja kultuurianimaatorite hulgas - siinkohal pean silmas ennekõike Lääne ajalugu, kuid ka Poolas on tegemist samalaadse nähtusega. Populaarsuse selline skaala ei soodustanud suulise ajaloo kui valdkonna akadeemilist "karjääri". Võimalik, et isegi kahjustas seda. Probleem seisnes ja seisneb Poolas tänapäevani selles, et suuliste ütluste kasutamine teaduseesmärkidel on olnud küsitav. Kui palju suulise ajaloo projekte on lõppenud intervjuude kogumise etapil? See on töö meeldivaim osa. Raskused hakkavad tekkima siis, kui soovitakse luua midagi enamat kui vaid ütluste kollaaži või avaldada efektseid tsitaate. Süüdistustele, et suuline ajalugu on üksnes mitterefleksiivne massiline meenutuste kogumine, kujunes 1980. aastatel nn lingvistilise läbimurde laineharjal vastuseks suulise ajaloo uus suund. Koos selle suuna tegevusega tuli vaatevälja ka jutustaja mõiste. Selle termini juurutamisel ajalooteadusse oli lingvistilise läbimurde kõrval oluline roll ka kvalitatiivsel sotsioloogial ja selle raames kasutataval biograafilisel meetodil. See meetod hõlmab mitmeid materjali kogumise ja analüüsi tehnikaid: räägitakse autobiograafiast, eluloost, elukäigu-uuringutest, erinevatest intervjuuliikidest, sh jutustav intervjuu. Biograafilise meetodi hüppelises arengus mängis suurt rolli postmodernistlik epistemoloogiakriis. Klassikalises metodoloogias käsitati autobiograafilist jutustust, nii suulist kui ka kirjalikku, otsese teabeallikana kellegi elu uurimiseks (Blumer 2007). Norman Denzin, üks biograafilise meetodi nüüdisaegse kontseptsiooni loojaist ja postmodernismi poolehoidjaist, kirjutas ühelt poolt keele läbipaistmatusest, võimatusest kiigata jutustaja ellu, kuid ühtlasi tunnistas, et biograafilise meetodi keskne tunnus on reaalse isiku olemasolu. Sel isikul on emotsioonid ja ta kutsub esile emotsioone teistes inimestes; ta elab "tõeliselt" (Denzin 1989). Epistemoloogiline debatt sundis biograafilist meetodit täiustama. Teoreetilis-metodoloogilisest seisukohast seostati Fritz Schützi ettepanekul ühelt poolt sümboliline interaktsionism, sotsiaalne fenomenoloogia ja etnometodoloogia ja teiselt poolt materjalide hermeneutilislingvistilised analüüsipõhimõtted. Suulise ajaloo akadeemiline versioon Poolas on tugevasti määratud just selle metodoloogiaga (Kaźmierska 1999, 2004; Rakuszewska-Pawełek 2002). Huvitav, ja minu arvates ka Poola suulisele ajaloole iseloomulik on see, et Schützi meetodi põhimõtete järgi töötavad ka Ajalooga Kohtumise Maja - keskuse Karta kogenud dokumentalistid, kes ühendavad paradoksaalselt kaks nomenklatuuri: ajaloo tunnistaja ja jutustaja, mille tulemuseks on kaks erinevat epistemoloogilist lähenemisviisi. 
Suuline ajalugu on Poolas muutumas üha populaarsemaks, kuid näib, et see ei toimu käsikäes julge ja tõsise aruteluga suulise ajaloo tuleviku üle. Mis toimub peale ajaloo tunnistajate ütluste kogumise ja nende kasutamise illustratiivsetel eesmärkidel näitustel ja filmides? Mis hakkab toimuma pärast sedastusi, et nüüd tekivad arhiivid tulevastele ajaloolaste põlvkondadele? Ei arutleta tunnistuste vormi ja edastuse üle, sest rahuldutakse andmete massilisuse kui faktiga iseenesest. Ajaloolased, kes tegelevad positivistlikust paradigmast lähtudes, peavad ajaloo tunnistajate ütluste temaatikat ja moraalset kaalu üllaks. Nad ei taha mõista, et nad loovad ühiselt samalaadseid allikaid, kohandades neid oma minevikupildiga, luues minevikutõlgendusi oma põhimõtetele tuginedes. Võib-olla hakkavadki tulevased ajaloolaste põlvkonnad neid allikaid kasutama, kuid siis hoopis muudel, mitte praegu eeldatavatel eesmärkidel. See eesmärk võib näiteks vastata küsimusele, kuidas mõista Poolas 21. sajandi alguses valitsevat minevikuteemalist arutelu.

\section{Kirjandus}

Blumer, Herbert 2007. Interakcjonizm symboliczny. Perspektywa i metoda [Sümbolistlik interaktsioon. Perspektiiv ja meetod]. Kraków: Zakład Wydawniczy "Nomos".

Denzin, Norman K. 1989. Interpretive Biography. London: Sage Publications.

Frisch, Michael 1990. A Shared Authority. Essays on Craft and Meaning of Oral and Public History. Albany, New York: State University of New York Press.

Holzer, Jerzy 1990. Oral History in Poland. BIOS: Zeitschrift für Biographieforschung und Oral History, Special Issue, lk 45-46.

Kałwa, Dobrochna 2010. Historia mówiona w krajach postkomunistycznych. Rekonesans [Suuline ajalugu postkommunistlikes riikides]. Kultura $i$ Historia 18 (http://www. kulturaihistoria.umcs.lublin.pl/archives/1887 - 8. jaanuar 2014).

Kaźmierska, Kaja 1999. Doświadczenia wojenne Polaków a ksztattowanie tożsamości etnicznej. Analiza narracji kresowych [Poolakate sõjaaegsed kogemused ja etnilise identiteedi kujunemine. Narratiivide analüüs]. Warszawa: IFiS PAN.

Kaźmierska, Kaja 2004. Wywiad narracyjny jako jedna z metod w badaniach biograficznych [Narratiivintervjuu kui üks biograafiliste uurimuste meetodeid]. Przegląd Socjologiczny 1 [Sotsioloogiline ülevaade], lk 71-96.

Kersten, Krystyna 1968. Relacje jako typ źódta historycznego,[w:] Pamiętnik X Powszechnego Zjazdu Historyków Polskich w Lublinie, 17-21 września 1968 r. Referaty plenarne. Sekcje VII-XI [Ütlused kui ajalooallika liik. 17.-21. septembril 1968 Lublinis toimunud X Poola ajaloolaste üldkongressi päevik. Plenaarreferaadid. VII-XI osa]. Warszawa, lk 316-329. 
Kersten, Krystyna 1971. Historyk - twórcą źródeł [Ajaloolane - allikate looja]. Kwartalnik Historyczny LXXVIII, lk 313-329.

Kostro, Robert \& Merta, Tomasza (toim) 2005. Pamięć i odpowiedzialność [Mälu ja vastutus]. Kraków, Wrocław: Ośrodek Myśli Politycznej - Centrum Konserwatywne.

Kubiszyn, Marta. 2003. Historia (nie)mówiona [(Mitte)suuline ajalugu]. Scriptores 2, lk 91-105.

Kurkiewicz, Michał. 2009. Opowiem ci jak przygotować notacje [Räägin sulle, kuidas koostada ülestähendusi] (http://www.ceo.org.pl/sites/default/files/news-files/opowiem_ jak_przygotowac_notacje_kurkiewicz.pdf - 8. jaanuar 2014).

Kurkowska-Budzan, Marta 2003. Historia zwyktych ludzi. Wspótczesna angielska historiografia dziejów społecznych [Tavaliste inimeste ajalugu. Kaasaegne inglise ühiskondliku ajaloo historiograafia]. Kraków: Historia Iagiellonica.

Markowski, Andrzej (toim) 1999. Nowy stownik poprawnej polszczyzny [Poola keele uus õigekeelsussõnaraamat]. Warszawa: Wydawnictwo Naukowe PWN.

Pietrasiewicz, Tomasz 2010. Archiwum Ośrodka "Brama Grodzka-Teatr NN" [Keskuse Brama Grodzka-Teatr NN arhiiv] (http://www.tnn.pl/Tradycja_opowiadania,1704.html - 8. jaanuar 2014).

Rokuszewska-Pawełek, Anna 2002. Chaos i przymus. Trajektorie wojenne Polakówanaliza biograficzna [Kaos ja sundus. Poolakate sõjatrajektoorid - biograafiline analüüs]. Łódź: Wydawnictwo Uniwersytetu Łódzkiego.

\section{Veebilehed (viimane külastus 8. jaanuaril 2014)}

Museum Powstawia Varszawskiega [Varssavi ülestõusu muuseum]: http://www.1944.pl Audiohistoria [audioajalugu]: http://www.audiohistoria.pl

Instytut Pamięci Narodowej [rahvusliku mälu instituut]: http://ipn.gov.pl/o-ipn/nagrodakustosz-pamieci-narodowej ja instituudi uurimisprojekt "Ülestähendused": http://ipn. gov.pl/bep/projekty-dokumentacyjne/program-notacje

Narodowe Centrum Kultury [rahvuslik kultuurikeskus]: http://www.nck.pl

Światkowie historii [ajaloo tunnistajad]: http://www.swiadkowiehistorii.pl

Lublini keskus Brama Grodzka [linnavärav] - Teatr NN: http://www.tnn.lublin.pl

Telekanal TVP: http://vod.tvp.pl/audycje/historia/notacje-historyczne 


\title{
Summary
}

\section{Witness to history or the specifics of oral history in Poland}

\author{
Marta Kurkowska-Budzan
}

Keywords: oral history, Poland, politics of memory, public history, a witness to history

In most of the countries of Central and Eastern Europe, oral history was initiated in the circles of dissidents in the 1980s. Memories of the politically marginalised or persecuted citizens were the source of insights into uncensored versions of recent past. Therefore the term "a witness to history" is central to the "civic historiography", which has been developed in Poland.

After the fall of communism, the civic participation in the archiving, educating and researching has been institutionalised and identifies itself as oral history.

The article presents epistemological and ethical paradoxes of the concept of "a witness to history" in the light of social and linguistic practice, as well as its historiographical and political usage. Examples of major oral history projects actively present in the public space and state and public institutions, influencing oral history practice in Poland, are presented. In the analysis of such institutions as the Warsaw Uprising Museum or the Institute of National Memory, the author focuses on their definition of "a witness to history" and places their practices in the context of the politics of memory implemented in Poland since 2005. Apart from the abovementioned powerful social players in the serious game of memory, knowledge and imagination, there are, however, other social actors contributing to the notion of oral history and creating an alternative vision of its tasks.

The author sketches two modes of the development of oral history in Poland - academic and public oral history - pointing at the concepts of 'narrator' and 'a witness to history', and briefly summarises the main problems of contemporary dominant practice. 